\title{
SCIENTIFIC AND PRACTICAL PRINCIPLES OF THE NATIONAL VARIETAL RESOURCES FORMATION: CURRENT STATE AND PROSPECTS
}

Melnyk S. I.

\section{INTRODUCTION}

The main task of the agricultural policy of Ukraine today is to raise productivity and improve the quality of crop production by increasing and maintaining varietal plant resources which determine the food security of the state and can be used in the further selection process ${ }^{1}$.

With the biological science development and the increase demands of agrarian market in providing agriculture with high-quality resources of plant varieties, the state ensures the quality of registration of cultivated in Ukraine varieties, the protection of plant breeders' rights and the introduction of seed certification in Ukraine in accordance with the international requirements.

Variety plant resources play a special role in the economic and social development of Ukraine, first of all, in stabilizing and increasing the volume of crop production as a basis for the country's food security.

The State Register of varieties, valuable for cultivation in Ukraine, includes more than 11 thousand varieties of about 450 botanical taxa of agricultural, cereal, vegetable, fruit, ornamental and other groups of plants which varieties are cultivated now ${ }^{2}$.

Formation of the national plant variety resources is based on the results of state scientific and technical examination of plant varieties. Every year, the State Register of varieties, valuable for cultivation in Ukraine, is replenished by the new varieties that meet the criteria of distinctness, uniformity and stability and meet the needs of consumers, do not endanger the human health and do no harm to the environment by commercially valuable characteristics ${ }^{3}$. It is exactly this testing that ensures the quality of national varietal resources

1 Shubravska O. V. (2010) Innovatsiini transformatsii ahroprodovolchoho sektora ekonomiky: svitovi tendentsii ta vitchyzniani realii. [Innovative transformations of the agri-food sector of the economy: global trends and domestic realities] Ekonomika i prohnozuvannia [Economy and forecasting] № 3, pp. 90-102.

${ }^{2}$ Derzhavnyi reiestr sortiv roslyn, prydatnykh dlia poshyrennia v Ukraini na 2019 [State register of plant varieties valuable for distribution in Ukraine for 2019] https://sops.gov.ua/reestrsortiv-roslin.

3 Mizhnarodna Konventsiia z okhorony novykh sortiv roslyn vid 2 hrudnia 1961 r., perehlianuta v m. Zheneva 10 lystopada 1972 r., 23 zhovtnia 1978 r. ta 19 bereznia 1991 r. Ofitsiinyi pereklad. (2006). [International Convention for the Protection of New Varieties of Plants of 2 December 1961, revised in Geneva on 10 November 1972, 23 October 1978 and 19 March 1991]. Kyiv: Alefa. 
formation and use. Finally, varietal research is the scientific study of plant varieties in the field and laboratory conditions in order to obtain complete knowledge of valuable characteristics (morphological, physiological, economical, etc) and worthiness of using them to meet the needs of consumers and in the further selection process ${ }^{4}$.

The lack of information related to the response to extreme environmental factors, resistance to pathogens and pests of the new cultivated in Ukraine varieties remains as an urgent problem. Comparative analysis between the degree of these characteristics manifestation and the results of scientific and technical expertise can be conducted by post-registration study (hereinafter PRS), which will allow to determine not only the economic feasibility of further cultivation, but also influence on the volume and structure of the sown areas in the certain regions of the country.

The quality characteristics of the varieties obtained during PRS will allow identifying the most environmentally friendly zones for processing, food and pharmacological industries ${ }^{5}$.

The optimal solution to the problem of the national plant variety resources formation is based on the results of the monitoring in countries of the Commonwealth of Independent States (CIS), the European Union (EU) and the International Union for the Protection of New Varieties of Plants (UPOV) ${ }^{6}$.

This makes it possible to say that the development of breeding in plantgrowing plays a crucial role in the varietal plant resources formation, and the state scientific and technical examination of plant varieties through the regulatory, controlling and advisory mechanisms is the single-source to ensure the formation and legal protection of varietal plant resources.

Analysis of the variety quality characteristics in dynamics along the process of economic, biological, consumer and intellectual value transformation will create the conditions for fund and effort targeting in the genetic bank formation and certification of the plant varieties as the basis for state food security ${ }^{7}$.

${ }^{4}$ Pro nasinnia i sadyvnyi material: Zakon Ukrainy vid 26.12.2002 roku № 411-IV [Law on Seeds and Planting Materials dated 26 December 2002, № 411-IV]. http://zakon4.rada.gov.ua/ laws/show/411-15.

${ }^{5}$ Ukrainian Institute for Plant Variety Examination (2016) Metodyka provedennja kvalifikacijnoji ekspertyzy sortiv roslyn na prydatnistj do poshyrennja $v$ Ukrajini. Zaghaljna chastyna. [Methods of conducting qualitative examination of plant varieties valuable for distribution in Ukraine. The common part] Kyiv: Niland-LTD.

${ }^{6}$ Dyrektyva Rady 2002/53/YS vid 13 chervnia 2002 roku pro spilnyi kataloh sortiv vydiv silskohospodarskykh roslyn (OB L 193, 20.07.2002, s. 1) [Council Directive 2002/53 / EU of 13 June 2002 on the common catalog of varieties of agricultural plant species (OB L 193, 20.07.2002, p. 1). https://www.kmu.gov.ua/storage/app/media/uploaded-files/es-2015412.pdf.

${ }^{7}$ Volkodav V.V. (2005) Pravova okhorona sortiv roslyn v Ukraini [Legal protection of plant varieties in Ukraine] Sortovyvchennia ta okhorona prav na sorty roslyn [Plant Varieties Studying and Protection], № 1, pp. 98-109. DOI: https://doi.org/10.21498/2518-1017.1.2005.66870. 


\section{Historical aspects of the plant variety resources formation in Ukraine}

The year 1923 is considered to be the beginning of the system of domestic variety examination, when the All-Ukrainian Society of Seed Production created a special research network, the tasks of which included only varietal testing of maize,

spring and winter wheat and potatoes ${ }^{8}$. Later (1927-1930) the program of variety examination was significantly expanded - all major field and garden crops were involved to it. Then, a universal methodology to study the plant varieties was developed for the first time and the list of plant varieties with the main variety features was formed in accordance with the local soil-climatic conditions of different regions. The autonomous network of variety examination of the Ukrainian People's Commissariat of Agriculture and the All-Ukrainian Society of Seed Production, as on 1928 with the main State Variety Network numbered 26 units. Economic and organizational work in the units of plant examination is shown in the Figure 1.

In 1932, the Ukrainian variety network for plant examination of the Ukrainian People's Commissariat of Agriculture was merged with the variety testing department of the All-Union Institute of Plant Growing (Moscow) and the All-Union State Variety Testing Network (State Grid Network) was created (later the State Commission on Variety Testing).

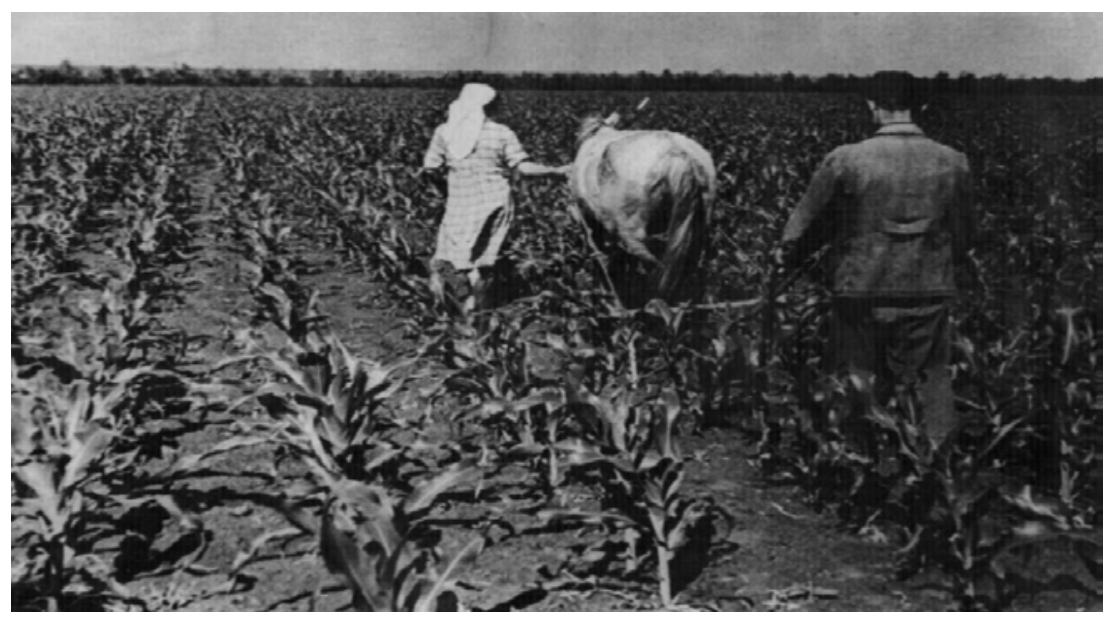

Fig. 1. Plant care at the maize experimental plot

${ }^{8}$ Vasyliuk P. M. (2013) Stanovlennia ta rozvytok naukovykh zasad sortovyprobuvannia $v$ Ukraini [Formation and development of scientific foundations of variety testing in Ukraine]. Kyiv: Niland-LTD. 
The decree of the Soviet People's Commissar of the USSR of 29.07.1937 "On Measures to Improve Cereal Seeds" laid out the principles of testing the varieties of cereals, including the establishment of a network of state variety experimental plots.

During the period 1937-1938, 193 plots were organized in the Ukrainian Republic: Vinnytsia region - 25, Dnipropetrovsk - 30, Donetsk 26, Odessa - 30, Kharkiv - 35, Chernihiv - 16.

In Ukraine, even before the World War II, 150 plots were organized to test cereals, oilseeds and herbs. The network of variety centers was formed according to the district principle (each district or group of districts with similar soil and climatic conditions).

Almost all cultivated plants were under examination and field testing was designed in accordance with 2, 3 or 6-fold replications. Due to seed control laboratory tests, the varieties were examined not only for yield, pest resistance, climatic conditions resistance, but also determined flour and baking quality of grain, protein and gluten content, diastatic activity of flour, etc.

The results obtained together with the results of the soil survey made it possible to develop varietal zoning.

In 1940, the variety experimental plots of extended set and of main network were formed in order to improve the quality of work, to ensure a comprehensive study of the economically valuable features of the variety and to ease strains on the main "State Variety Network". The general view of field experiments on experimental plots is shown in Fig. 2.

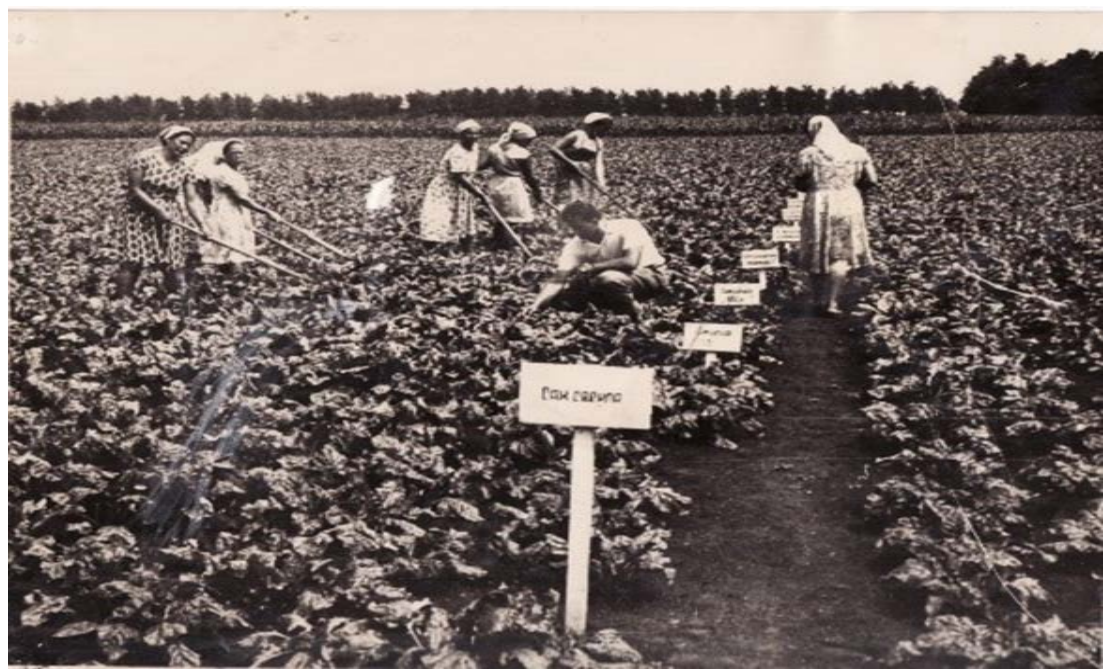

Fig. 2. Plant care during the field examination 
In the early 50es of the last century, through the organization of variety examination plots at the collective and state farms the variety examination activity was raised up to the pre-war level.

The number of variety experimental plots in the Soviet Ukrainian Republic increased to 225.

As of the beginning of 1970, the main functions of the state variety examination network were and remain to give an objective and accurate comparative evaluation of varieties and hybrids of crops, identification of more yielding and valuable varieties for zoning and their introduction into agricultural production.

The general provisions of the variety examination methodology are uniform for all experimental plots, regardless of their specialization, production base and geographical location.

As of November 1, 1985, the network of variety examination stations and plots of the Ukrainian SSR included 258 units, of which, on the basis of collective farms - 154, state farms and other enterprises -86 , on an independent balance - 17, 1 - specialized variety examination station.

In accordance with the Decree of the Council of Ministers of the UkrSSR of 27.12.1989 №292 "On the organizational structure of state examination and zoning of crop varieties" the Inspectorate of the State Commission for Crops Variety Examination in the UkrSSR was reorganized into the State Commission for Agricultural Crops Examination of the Main State Agricultural Industry (hereinafter Commission), which included the network of institutions: 25 regional inspectorates, 8 regional state stations for plant variety examination, 17 state experimental plot centers and Ukrainian central laboratory for testing the quality of variety examination in Kyiv. Field experiment is shown in Fig. 3.

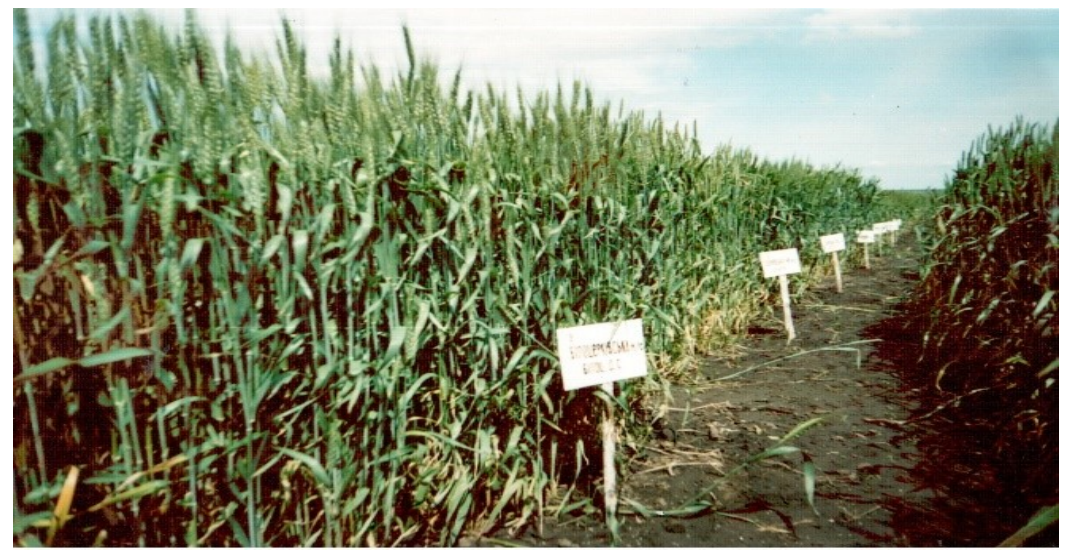

Fig. 3. Feald examinatin of maize varieties 
In accordance with the Decree of the Council of Ministers of the UkrSSR of 27.12.1989 № 292 "On the organizational structure of state examination and zoning of crop varieties" the Inspectorate of the State Commission for Crops Variety Examination in the UkrSSR was reorganized into the State Commission for Agricultural Crops Examination of the Main State Agricultural Industry (hereinafter Commission), which included the network of institutions: 25 regional inspectorates, 8 regional state stations for plant variety examination, 17 state experimental plot centers and Ukrainian central laboratory for testing the quality of variety examination in Kyiv.

The main task of the Commission was to implement state examination of all new varieties, hybrids and lines of domestic and foreign breeding ${ }^{9}$.

In 1992 the State Commission for Agricultural Crops Examination of the Main State Agricultural Industry of the UkrSSR was renamed to the State Commission of Ukraine for Examination and Protection of Plant Varieties of the Ministry of Agrarian Policy and Food of Ukraine (State Commission), which carried out state administration of field plant variety examination.

The purpose of its creation was to ensure public administration of the plant varietal resources formation of Ukraine and the protection of breeders' rights.

The State Commission numbered 25 regional inspectorates, 66 regional state stations for plant variety examination, 122 stations for plant variety examination, 8 laboratories and 4 enterprises.

Decree of the Cabinet of Ministers of Ukraine 3116-XII of 21.04.1993 adopted the Law of Ukraine "On Protection of Plant Variety Breeders' Rights", which provides regulation of property and personal non-property relations arising in connection with the acquisition, exercise and protection of intellectual property rights on plant varieties.

Pursuant to the Law, the Decree of the Cabinet of Ministers of Ukraine № 935 of 22.11.1993 “On the Register of Plant Varieties of Ukraine” approved the Regulation on the Register of Plant Varieties of Ukraine, and adopted a number of by-laws regulating acts for the Register introduction ${ }^{10}$.

Formation of the State Register of Plant Varieties of Ukraine allowed to create internal market for varieties and hybrids and accelerate their introduction into production, eliminates artificial restrictions of their use and gives producers more rights to choose the best varieties according to seed potential.

${ }^{9}$ Diialnist ta istoriia Ukrainskoho instytutu ekspertyzy sortiv roslyn (2019) [Activity and History of Ukrainian Institute for Plant Variety Examination] https://sops.gov.ua/istoria-uiesr-2.

${ }^{10}$ Pro okhoronu prav na sorty roslyn: Zakon Ukrainy vid 21.04.1993 roku № 3116- XII [The Law On Protection of Rights to Plant Varieties of 21.04.1993 № 3116-XII]. http://zakon4.rada.gov.ua/laws/show/3116-12. 
In 1995, Ukraine became a member of the International Union for the Protection of New Varieties of Plants (UPOV). The Verkhovna Rada of Ukraine adopted the Law of Ukraine of June 2, 1995 № 209/95-VR "On Accession of Ukraine to the International Convention for the Protection of New Varieties of Plants".

And in 1997, cooperation between Ukraine and the Organization for Economic Co-operation and Development (OECD) was initiated through the signing Agreement on Privileges, Immunities and Benefits Granted to the OECD in Ukraine.

The agreement was ratified by the Verkhovna Rada of Ukraine in July 1999 (Law of Ukraine dated 07.07.99 № 850-XIV).

In 2000, the variety examination network of the State Commission of Ukraine for Plant Varieties Examination and Protection of the Ministry of Agriculture and Food of Ukraine numbered 92 regional state stations for plant variety examination, and 47 experimental plot centers.

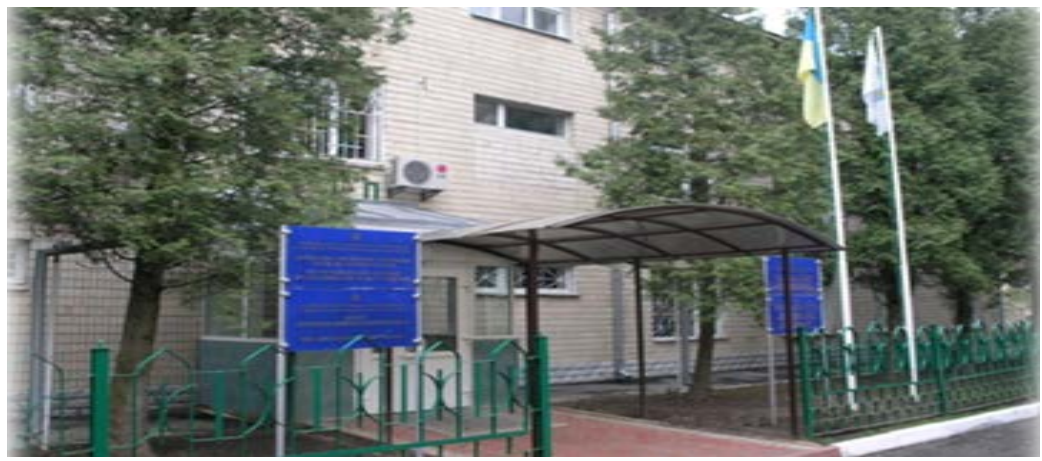

Fig. 4. Ukrainian Institute for Plant Variety Examination

New approaches to the concept of the variety and the world experience in right protection have prompted the government to take appropriate steps to develop legal, scientific, methodological and international components of the system of variety examination and rights protection. The decree of the Cabinet of Ministers of Ukraine in 2001 approved a number of top priority measures for solving the most important tasks of seed production and crop breeding, and provided the establishment of the Ukrainian Institute for Plant Variety Examination ${ }^{11}$.

${ }^{11}$ Analitychna zapyska pro riven rozvytku naukovoho (naukovo-tekhnichnoho) potentsialu i rezultatyvnosti diialnosti Ukrainskoho instytutu ekspertyzy sortiv roslyn ta obgruntuvannia napriamiv i zakhodiv z optymizatsii diialnosti Ustanovy za 2015-2017 roky. [Analytical note on the level of development of scientific (scientific and technical) potential and performance of the Ukrainian Institute for Plant Variety Examination and substantiation of directions and measures for optimization of the Institute's activities for 2015-2017]. https://sops.gov.ua/uploads/page/images. 
In 2002, the Ukrainian Institute for Plant Variety Examination (UIPVE) was created through the reorganization of the State Center for Certification, Identification and Quality of Plant Varieties of the State Commission for Plant Varieties Examination and Protection of the Ministry of Agrarian Policy (Cabinet of Ministers of Ukraine of 01.06.2002, №714 "On Establishment of the State Service for plant varieties protection and UIPV”) ${ }^{12}$.

Within the Ministry of Agrarian Policy and Food, the State Commission for Plant Variety Rights Protection was established on the basis of the State Commission of Ukraine for Plant Varieties Examination and Protection, and UIPVE and experimental plot centers were subordinated to this governmental body.

In 2003, the UIPVE launched the publication of the official Bulletin "Protection of Plant Variety Rights", aimed officially publishing the results of research on the basis of which state registration of the variety and/or its rights is conducted. In 2003, the Verkhovna Rada of Ukraine adopted the Law of Ukraine № 411-IV of 26.12.2003 "On seeds and planting material", which defined the basic principles of production and circulation of seeds and planting materials, as well as the procedure for state control over them ${ }^{13}$.

Cooperation between Ukraine and the Community Plant Variety Office (CPVO) was initiated in 2005. On April 25, 2005, a Memorandum of Understanding between the CPVO and the State Commission for Plant Variety Rights Protection was signed in Kyiv, that include exchange of information, experience, training and technical cooperation (training of technical staff, participation of Ukrainian representatives as observers in CPVO expert meetings) ${ }^{14}$.

The Verkhovna Rada of Ukraine adopted the Law of Ukraine of 02.08.2006 № 60-V “On Accession of Ukraine to the International Convention for the Protection of New Varieties of Plants".

Ratification of the 1991 Act of the International Convention for the Protection of New Varieties of Plants allowed protecting plant varieties of all botanical taxa.

${ }^{12}$ Leshchuk N. V., Rudnyk O. I. (2002) Isnuiucha systema sortovyprobuvannia ta identyfikatsiia sortiv silskohospodarskykh kultur [Existing system of variety testing and identification of crops varieties] Naukovyi visnyk Natsionalnoho ahrarnoho universytetu [Scientific Bulletin of the National Agrarian University], № 57, pp. 143-146.

${ }^{13}$ Volkodav V. V. (2012) Zakonodavche udoskonalennia haluzi nasinnytstva - zaporuka vysokykh i stalykh vrozhaiv [Legislative improvement of the seed industry is the key to high and sustainable crops]. Naukovyi visnyk Natsionalnoho universytetu bioresursiv i pryrodokorystuvannia Ukrainy. [Scientific Bulletin of the National University of Life and Environmental Sciences of Ukraine] Ser.: Ahronomiia, № 176. Pp. 301-306.

${ }^{14}$ Pushkar M. V. (2005) Do pytannja systematyzaciji zakonodavstva Ukrajiny u sferi intelektualjnoji vlasnosti na sorty roslyn [On the systematization of the legislation of Ukraine in the field of intellectual property for plant varieties] Visnyk ghospodarsjkogho sudochynstva [Bulletin of economic justice]. № 5. Pp. 167-173. 
Year by year the material and technical base of the state system for plant varieties protection was strengthened and a team of professional specialists was formed. Today, there are 24 regional state centers for plant varieties examination (branches) in the structure of the Ukrainian Institute for Plant Variety Examination with 96 scientists, including 4 professors and 24 doctors. Scientific and methodological support provides high quality of field and laboratory researches for plant examination, Fig. 5.

In 2013, Ukraine ensured the holding of the 42nd session of the UPOV Technical Working Group on Field Crops in Ukraine (Kyiv), which was attended by 58 foreign participants from 30 countries (UPOV member countries) $)^{15}$.

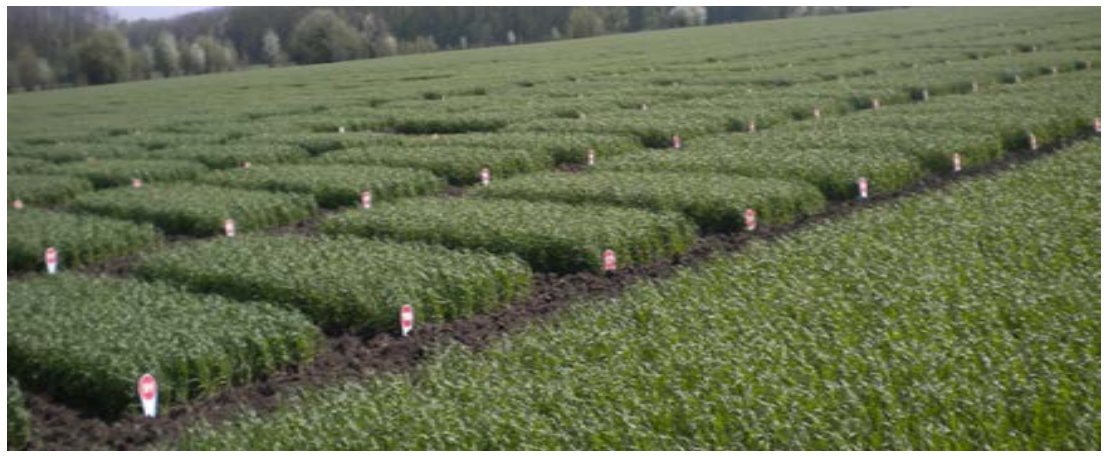

Fig. 5. Field examination 2013

Ukraine also closely works with the intergovernmental Organization for Economic Cooperation and Development (OECD) as an associate member: it has joined the OECD Seed Schemes for the certification of cereal, maize, sorghum, oilseed, cruciferous and sugar beet seeds. The OECD conducts regular peer reviews in the member countries.

Conducting such a review in Ukraine contributes to the deepening of cooperation with the OECD, is of great practical importance as it contains specific recommendations for improving public policy in the field of variety identification and variety certification of seeds and planting materials ${ }^{16}$.

${ }^{15}$ Dehtiarenko Yu. (2018) Aktualni ta problemni pytannia zakonodavstva Ukrainy u sferi okhorony sortiv roslyn u spivvidnoshenni z uhodoiu pro asotsiatsiiu z YeS [Current and problem issues of Ukrainian legislation in the field of protection of plant varieties in the context of the European Union Association Agreement] Teoriia i praktyka intelektualnoi vlasnosti. [Theory and Practice of Intellectual Property], № 5, pp.75-82.

${ }^{16}$ Tkachyk S.O., Leshchuk N.V., Hryniv S.M., Kostenko N.P. (2018) Metodyka provedennja diljankovogho (gruntovogho) ta laboratornogho sortovogho kontrolju (POSTcontrol). [Methods of conducting the site (soil) and laboratory varietal control (POST-control)], Vinnytsia: Niland-LTD. 


\section{Concept of national varietal resources formation}

The market of seeds and planting materials of plant varieties puts forward urgent requests, namely: assortment, pure-seed, its authenticity; maximum of criteria, minimum of conditions; State Register of Plant Varieties (National Catalog): support examination on distinctness, uniformity, stability and suitability for cultivation in Ukraine; quality certification system: compliance with international requirements, coordination and transparency of actions; pre-registration and post-registration study of varieties, with further formation of regional lists ${ }^{17}$.

Modern methods and directions of plant variety selection provide quality product for market needs.

Current priorities in the selection practices of plant varieties are the criteria that should ensure: yield (positive dynamics), resistance against pathogens and pests, resistance to abiotic stress, productivity potential, product quality, yield efficiency, nutritional quality and product safety, qualitative storage, optimal cost, more efficient land use, economic viability, new markets and variety competitiveness ${ }^{18}$.

An important factor is the annual filling of the Register of Ukraine by the new competitive plant varieties. The analysis of variety replacement along the last 5 years for strategic crops of grain group in Ukraine is $55-71 \%$ (Table 1).

Further formation of the national varietal plant resources requires improving the mechanism of its legislative, regulatory, methodological, organizational, staff, scientific, technical, technological and financial regulation in accordance with international and European requirements ${ }^{19}$. The concept of the national varietal plant resources formation for 2006-2011 revealed the causes of unbalanced system of its formation:

- mismatch of actual crop production volumes to the needs of the internal and external markets due to inefficient use of varietal plant resources induced by the post-registration research absence;

- unregulated market relations in the civil circulation of plant varieties, which leads to imbalance in supply and demand on the market of plant varieties;

${ }^{17}$ Andriushchenko A. V., Tkachenko V. M. (2011) Pro neobkhidnist perehliadu Metodyky derzhavnoho vyprobuvannia sortiv roslyn na prydatnist do poshyrennia v Ukraini. [On the need to review the methodology of state VCU testing of plant varieties Ukraine] Sortovyvchennia ta okhorona prav na sorty roslyn. [Plant Varieties Studying and Protection] № 1, pp. 55-57. DOI: https://doi.org/10.21498/2518-1017.1(13).2011.60076.

${ }^{18}$ Haievets M. V. (2012) Superechlyvist norm zakonodavstva Ukrainy u zdiisnenni derzhavnoi reiestratsii prav intelektualnoi vlasnosti na sorty roslyn. [The controversy of the norms of Ukrainian legislation in the registration of intellectual property rights to plant varieties]. Teoriia i praktyka intelektualnoi vlasnosti [Theory and Practice of Intellectual Property], № 3, pp. 6-10.

${ }^{19}$ Zakharchuk O. V. (2009) Sort yak innovatsiina osnova rozvytku roslynnytstva [Variety as an innovative basis of crop development] Ahroinkom, № 5/8, pp. 17-22. 
Rates of variety replacement in the State Register of Plant Varieties Valuable for Cultivation in Ukraine

\begin{tabular}{|l|c|c|c|c|}
\hline \multirow{2}{*}{ Botanical taxa } & \multicolumn{3}{|c|}{$\begin{array}{c}\text { Variety amount } \\
\text { in the Register }\end{array}$} & \multirow{2}{*}{$\begin{array}{c}\text { \% of replacement during } \\
\text { 2015-2019 }\end{array}$} \\
\cline { 2 - 5 } & $\mathbf{2 0 0 5}$ & $\mathbf{2 0 1 5}$ & $\mathbf{2 0 1 9}$ & 70 \\
\hline soft winter wheat & 111 & 313 & 218 & 56 \\
\hline sowing rye & 29 & 34 & 19 & 55 \\
\hline spring barley & 79 & 129 & 71 & 71 \\
\hline soft spring wheat & 35 & 45 & 32 & 65 \\
\hline maize & 291 & 880 & 568 & 62 \\
\hline sunflower & 138 & 583 & 363 & 52 \\
\hline sugar beet & 96 & 169 & 87 & 24 \\
\hline potatoes & 107 & 180 & 43 & 69 \\
\hline soybean & 72 & 166 & 115 & \multicolumn{3}{|c|}{} \\
\hline
\end{tabular}

- low rates of scientific and technical potential realization in plant selection;

- insufficient state motivation and support in plant variety domestic breeding and seed development;

- the lack of a modern genetic bank of varietal plant resources;

- insufficient financial, material, technical, scientific, staff, information and consulting support in the state scientific and technical examination of plant varieties ${ }^{20}$.

With that in mind, appeared the need to create a new concept of national varietal plant resources formation and their effective use ${ }^{21}$. The main tasks of the concept of national varietal plant resources formation are:

- state regulation of plant varieties civil circulation and creation of competitive varieties of domestic breeding, variety certification introduction and international market entry;

${ }^{20}$ Kontseptsiia formuvannia natsionalnykh sortovykh roslynnykh resursiv na 2006-2011 roky. Rozporiadzhennia Kabinetu Ministriv Ukrainy vid 2 serpnia 2005 r. № 302-r [The concept of national varietal plant resources formation for 2006-2011. Ordinance of the Cabinet of Ministers of Ukraine of August 2, 2005 № 302-p]. https://zakon.rada.gov.ua/laws/show/302-2005-\%D1\%80.

${ }^{21}$ Lypchuk V. V., Malakhovskyi D. V. (2015) Sortovi resursy zernovykh kultur v Ukraini: stan ta problemy rozvytku [The sorts resources of grain crops in Ukraine: status and problems of development] Innovatsiina ekonomika [Innovative economy], № 1, pp.12-17. 
- harmonization of the domestic policy related to intellectual property rights on plant varieties with the state policies of the countries - members of the European Union and other world leading countries;

- increasing the competitiveness of domestic crop production and products of its processing on the domestic and foreign markets.

The state funds allocated for the state scientific and technical examination of plant varieties are not enough, and the issue of attracting nonstate investments has not been resolved.

The issues of scientific and technical, personnel and information consulting support remain also unresolved. There is no mechanism for interaction between state and non-governmental scientific institutions and organizations in the process of national varietal plant resources formation ${ }^{22}$.

Such researches will form the organizational principles for scientifically sound monitoring of varieties and hybrids involved into commercial circulation based on the analysis of studies and modern European practice to decide independently the state registration of plant varieties for cultivation in Ukraine and the state registration of their rights.

This solution creates the conditions for involving community and the institute of intellectual property representatives for plant varieties as an expert bodies for consideration this issue ${ }^{23}$.

The problem of varietal plant resources formation is supposed to be solved through:

- ensuring the priority of the development of state system of plant variety rights protection in the implementation of domestic and foreign state policies in the budget, credit, price, insurance, tax and regulatory spheres;

- improving the legal framework related to the plant variety rights protection;

- development of mechanisms of interaction between state and nongovernmental institutions and organizations in ensuring the varietal plant resources formation;

- development of scientific and technical, innovative activity and standardization in the field of intellectual property for plant varieties, including varietal study;

- formation of information, communication and consulting system of economic usability and protectability of plant varieties.

The varietal plant resources formation will be carried out at the expense of:

${ }^{22}$ Sabluk P.T., Khadzhymatov V. A., Kisilj M. I., Zakharchuk O. V. (2009) Normatyvni vytraty na provedennia ekspertyzy sortiv roslyn. [Standard costs for the examination of plant varieties]. Kyiv.

${ }^{23}$ Leshchuk N. V., Zribniak M. M. (2005) Derzhavna reiestratsiia sortiv ovochevykh kultur - osnova formuvannia natsionalnykh sortovykh resursiv [State registration of vegetable varieties is the basis for the national varietal resources formation] Sortovyvchennia ta okhorona prav na sorty roslyn [Plant Varieties Studying and Protection], № 2, pp. 86-96. 
- state budget funds, including revenues from payment of fees for actions related to the acquisition, exercise and protection of plant variety rights, as well as the provision of paid services for conducting a field and laboratory VCU research and other types of expertise and by-products realization, carrying out scientific-production activity of the state examination institutions of the system of plant varieties rights protection;

- funds of the International Charitable Foundation for the Protection of Intellectual Property and grants of international technical assistance;

- state fund for varietal plant resources formation.

The implementation of the concept will provide: solution of the state food security, creation of new domestic highly productive adapted plant varieties and introduction of varietal certification of seeds according to OECD requirements, production volume increase, quality and competitiveness of domestic production on the domestic and foreign markets, that will help to increase the annual gross income in the field of crop production.

\section{CONCLUSIONS}

The implementation of scientific research on the development of the Concept of national varietal plant resources formation for 2020-2025 will provide:

1. Solving the national food security question, creation of new domestic high-performance, adapted, competitive plant varieties.

2. Substantiation of post-registration variety study to form regional lists of plant varieties on request of economic entities of different forms of ownership.

3. Implementation of varietal certification of seeds and planting materials according to the international requirements of the Organization for Economic Cooperation and Development.

4. Increasing production and improving the quality of marketable products and seeds on the domestic and foreign markets.

5 . Increase in the annual gross income in the field of crop production by the category "Sort" by $25-50 \%$.

\section{SUMMARY}

Varietal plant resources play a special role in the economic and social development of Ukraine, first of all, in stabilizing and increasing the volume of crop production as a basis for the country's food security.

Varietal quality is a reliable and cost-effective factor in increasing crop yields under any growing technology. Modern varieties and hybrids must be distinctive, uniform and stable, meet the needs of consumers, without endangering the environment and human health. 
Research methods. Methods were used for research: field, laboratory, statistical, historical with elements of extrapolation, analysis and synthesis.

Research results. The historical aspects of the national varietal resources formation, the current state and prospects of development of the plant varieties rights protection are revealed. The reasons for the development of the Concept of National Varietal Resources Formation are substantiated, the tasks and ways of their realization are determined.

Conclusions. The implementation of the concept will provide: addressing the food security of the state, creation of new domestic highly productive adapted plant varieties and introduction of varietal certification of seeds according to OECD international requirements, increase production volumes, quality and competitiveness of domestic production on the domestic and foreign markets, which will help to increase the annual gross income in the field of crop production.

\section{REFERENCES}

1. Shubravska O. V. (2010) Innovatsiini transformatsii ahroprodovolchoho sektora ekonomiky: svitovi tendentsii ta vitchyzniani realii. [Innovative transformations of the agri-food sector of the economy: global trends and domestic realities] Ekonomika i prohnozuvannia [Economy and forecasting] № 3, pp. 90-102.

2. Derzhavnyi reiestr sortiv roslyn, prydatnykh dlia poshyrennia v Ukraini na 2019 [State register of plant varieties valuable for distribution in Ukraine for 2019] (in Ukrainian). https://sops.gov.ua/reestr-sortiv-roslin.

3. Mizhnarodna Konventsiia $\mathrm{z}$ okhorony novykh sortiv roslyn vid 2 hrudnia 1961 r., perehlianuta v m. Zheneva 10 lystopada 1972 r., 23 zhovtnia 1978 r. ta 19 bereznia 1991 r. Ofitsiinyi pereklad. (2006). [International Convention for the Protection of New Varieties of Plants of 2 December 1961, revised in Geneva on 10 November 1972, 23 October 1978 and 19 March 1991]. Kyiv: Alefa. (in Ukrainian).

4. Pro nasinnia i sadyvnyi material: Zakon Ukrainy vid 26.12.2002 roku № 411-IV [Law on Seeds and Planting Materials dated 26 December 2002, № 411-IV ]. (in Ukrainian) http://zakon4.rada.gov.ua/laws/show/ 411-15.

5. Ukrainian Institute for Plant Variety Examination (2016) Metodyka provedennja kvalifikacijnoji ekspertyzy sortiv roslyn na prydatnistj do poshyrennja $v$ Ukrajini. Zaghaljna chastyna. [Methods of conducting qualitative examination of plant varieties valuable for distribution in Ukraine. The common part] Kyiv: Niland-LTD. (in Ukrainian).

6. Dyrektyva Rady 2002/53/YS vid 13 chervnia 2002 roku pro spilnyi kataloh sortiv vydiv silskohospodarskykh roslyn (OB L 193, 20.07.2002, s. 1) [Council Directive 2002/53 / EU of 13 June 2002 on the common catalog 
of varieties of agricultural plant species (OB L 193, 20.07.2002, p. 1). (in Ukrainian) https://www.kmu.gov.ua/storage/app/media/uploaded-files/ es-2015412.pdf.

7. Volkodav V.V. (2005) Pravova okhorona sortiv roslyn v Ukraini [Legal protection of plant varieties in Ukraine] Sortovyvchennia ta okhorona prav na sorty roslyn [Plant Varieties Studying and Protection], № 1, pp. 98-109. DOI: https://doi.org/10.21498/2518-1017.1.2005.66870.

8. Vasyliuk P. M. (2013) Stanovlennia ta rozvytok naukovykh zasad sortovyprobuvannia $v$ Ukraini [Formation and development of scientific foundations of variety testing in Ukraine]. Kyiv: Niland-LTD. (in Ukrainian).

9. Diialnist ta istoriia Ukrainskoho instytutu ekspertyzy sortiv roslyn (2019) [Activity and History of Ukrainian Institute for Plant Variety Examination] https://sops.gov.ua/istoria-uiesr-2.

10. Pro okhoronu prav na sorty roslyn: Zakon Ukrainy vid 21.04.1993 roku № 3116- XII [The Law On Protection of Rights to Plant Varieties of 21.04.1993 № 3116-XII]. (in Ukrainian) http://zakon4.rada.gov.ua/laws/ show/3116-12.

11. Analitychna zapyska pro riven rozvytku naukovoho (naukovotekhnichnoho) potentsialu i rezultatyvnosti diialnosti Ukrainskoho instytutu ekspertyzy sortiv roslyn ta obgruntuvannia napriamiv i zakhodiv z optymizatsii diialnosti Ustanovy za 2015-2017 roky. [Analytical note on the level of development of scientific (scientific and technical) potential and performance of the Ukrainian Institute for Plant Variety Examination and substantiation of directions and measures for optimization of the Institute's activities for 2015-2017]. (in Ukrainian) https://sops.gov.ua/uploads/page/images.

12. Leshchuk N. V., Rudnyk O. I. (2002) Isnuiucha systema sortovyprobuvannia ta identyfikatsiia sortiv silskohospodarskykh kultur [Existing system of variety testing and identification of crops varieties] Naukovyi visnyk Natsionalnoho ahrarnoho universytetu [Scientific Bulletin of the National Agrarian University], № 57, pp. 143-146.

13. Volkodav V. V. (2012) Zakonodavche udoskonalennia haluzi nasinnytstva - zaporuka vysokykh i stalykh vrozhaiv [Legislative improvement of the seed industry is the key to high and sustainable crops]. Naukovyi visnyk Natsionalnoho universytetu bioresursiv i pryrodokorystuvannia Ukrainy. [Scientific Bulletin of the National University of Life and Environmental Sciences of Ukraine] Ser.: Ahronomiia, № 176, pp. 301-306.

14. Pushkar M. V. (2005) Do pytannja systematyzaciji zakonodavstva Ukrajiny u sferi intelektualjnoji vlasnosti na sorty roslyn [On the systematization of the legislation of Ukraine in the field of intellectual property for plant varieties] Visnyk ghospodarsjkogho sudochynstva [Bulletin of economic justice] № 5, pp. 167-173. 
15. Dehtiarenko Yu. (2018) Aktualni ta problemni pytannia zakonodavstva Ukrainy u sferi okhorony sortiv roslyn u spivvidnoshenni $\mathrm{z}$ uhodoiu pro asotsiatsiiu z YeS [Current and problem issues of Ukrainian legislation in the field of protection of plant varieties in the context of the European Union Association Agreement] Teoriia i praktyka intelektualnoi vlasnosti. [Theory and Practice of Intellectual Property], № 5, pp. 75-82.

16. Tkachyk S.O., Leshchuk N.V., Hryniv S.M., Kostenko N.P. (2018) Metodyka provedennja diljankovogho (gruntovogho) ta laboratornogho sortovogho kontrolju (POST-control). [Methods of conducting the site (soil) and laboratory varietal control (POST-control)], Vinnytsia: Niland-LTD. (in Ukrainian).

17. Andriushchenko A. V., Tkachenko V. M. (2011) Pro neobkhidnist perehliadu Metodyky derzhavnoho vyprobuvannia sortiv roslyn na prydatnist do poshyrennia v Ukraini. [On the need to review the methodology of state VCU testing of plant varieties Ukraine] Sortovyvchennia ta okhorona prav na sorty roslyn. [Plant Varieties Studying and Protection] № 1, pp. 55-57. DOI: https://doi.org/10.21498/2518-1017.1(13).2011.60076.

18. Haievets M. V. (2012) Superechlyvist norm zakonodavstva Ukrainy u zdiisnenni derzhavnoi reiestratsii prav intelektualnoi vlasnosti na sorty roslyn. [The controversy of the norms of Ukrainian legislation in the registration of intellectual property rights to plant varieties]. Teoriia $i$ praktyka intelektualnoi vlasnosti [Theory and Practice of Intellectual Property], № 3, pp. 6-10.

19. Zakharchuk O. V. (2009) Sort yak innovatsiina osnova rozvytku roslynnytstva [Variety as an innovative basis of crop development] Ahroinkom, № 5/8, pp. 17-22.

20. Kontseptsiia formuvannia natsionalnykh sortovykh roslynnykh resursiv na 2006-2011 roky. Rozporiadzhennia Kabinetu Ministriv Ukrainy vid 2 serpnia 2005 r. № 302-r [The concept of national varietal plant resources formation for 2006-2011. Ordinance of the Cabinet of Ministers of Ukraine of August 2, 2005 № 302-p]. (in Ukrainian). https://zakon.rada.gov.ua/ laws/show/302-2005-\%D1\%80.

21. Lypchuk V. V., Malakhovskyi D. V. (2015) Sortovi resursy zernovykh kultur v Ukraini: stan ta problemy rozvytku [The sorts resources of grain crops in Ukraine: status and problems of development] Innovatsiina ekonomika [Innovative economy], № 1, pp. 12-17.

22. Sabluk P.T., Khadzhymatov V. A., Kisilj M. I., Zakharchuk O. V. (2009). Normatyvni vytraty na provedennia ekspertyzy sortiv roslyn. [Standard costs for the examination of plant varieties]. Kyiv. (in Ukrainian).

23. Leshchuk N. V., Zribniak M. M. (2005) Derzhavna reiestratsiia sortiv ovochevykh kultur - osnova formuvannia natsionalnykh sortovykh 
resursiv [State registration of vegetable varieties is the basis for the national varietal resources formation] Sortovyvchennia ta okhorona prav na sorty roslyn [Plant Varieties Studying and Protection], № 2, pp. 86-96. DOI: https://doi.org/10.21498/2518-1017.2.2005.67469.

Information about the author: Melnyk S. I.,

Prof. Dr. of Economic, Director, Ukrainian Institute for Plant Variety Examination 15, Henerala Rodymtseva str., Kyiv, 03041, Ukraine ORCID ID: orcid.org/0000-0002-5514-5819 